\title{
Ethical Utopian Construction of Wolf Hall and Bring up the Bodies*
}

\author{
Yan Chunmei \\ Quzhou University, Quzhou, China
}

\begin{abstract}
Wolf Hall and Bring up the Bodies, two of Mantel's Tudor series, challenge the history and overturn the collective ideas of absoluteness. With irony structures, they invent a world of ethical utopian with distinctive features. Just as the construction of "the ideal country" and "the peach garden", the two novels construct a unique utopia of narrative discourses of modern fictions, in which the hero Cromwell's power of human nature has been revealed. They also reflect the author's ambition of reconstruct the whole social ethics.
\end{abstract}

Keywords: Wolf Hall, Bring up the Bodies, ethical utopia, the power of human nature

\section{Introduction}

More often than not, the driving force behind development of plots of a good novel stems from the inherent ironic tone (Yin, 1995). Mocking narrative, jocose attitude, paradoxical situation, etc., usually embodies the author's contemplation of external and internal world, and the witty taunt understanding of hardship, bitterness, and weight of life. Renowned literary critic Ceorg Lukacs observes that the overall irony structure of a novel is aimed at creating what does not exist in worldly life, namely Utopia (Lukács, 2004). Currently, such terms as "One World", "Never-never Land", "the Republic", and "Communism" are synonymous with "Utopia" and denotes "the imagined and wonderful land". Western communism takes "utopia" as a functional means of bestowing meaning on the world, and highlighting the criticism leveled at the "alienated" world by "utopia" concept (Wu, 2013). Frederic Jameson points out that the ultimate ethical purpose of human life is utopia, and novel narrative is the best way to construct a utopian world (Jameson, 1995). Hence, as exploration into possibilities of human, one of the fundamental aspects of novel narrative is the construction of ethical utopia.

Wolf Hall and Bring up the Bodies depicts Cromwell's rise from a man of humble birth to a man favored by the king. For one thing, the novel weaves a tapestry of politics, religion, and economy of England in the 16th century by shreds of distinctive characters and abundant historical events. For another, it talks about commonplace questions which find echo among virtually each ethnic group, i.e., relationship between a king and his subjects, relationship between husband and wife, family issues and friendship, etc. Imagination of history is a reappearance of reality and exposing and criticizing the false and ugly is the longing for and the pursuit of truth,

\footnotetext{
* Acknowledgements: This work is the initial result of "The Study of Hillary Mantel Novels From the Perspective of Ethnic Community Culture" (Project Number: 2013QN083) supported by key humanities and social science research project among universities in Zhejiang Province.

Yan Chunmei, associate professor, master, College of Foreign Languages, Quzhou University.
} 
goodness and beauty. By conceiving the denotative and connotative meaning of Wolf Hall and Bring up the Bodies, and creating satire through making Thomas Cromwell contrast sharply with Thomas More in the novel, Mantel purports to fabricate a distinctive ethical utopian world for readers. Thomas Cromwell is chosen as the perspective of narrative, and by illustrating vividly Cromwell's attitude towards the king, family, friends, and even enemies and mirroring ethical relations among individuals of the historical stage in question, Mantel shapes contemporary national community.

\section{Construction of Public Rational Spirit of Loyalty to the King and Patriotism}

Henry VIII has a nasty temper and is quite temperamental. He spends most of his time fooling around the court, writing love poems, hunting, and dueling. Besides, Henry VIII busies himself in getting rid of Anne Boleyn who could not breed male heirs, hoping Jane Seymour would fall for him. When serving Henry VIII, Cromwell, a man of political vision, always lives by the ethical principle of loyalty and patriotism. Cromwell would do anything he could to satisfy needs of Henry VIII, and help him with domestic and foreign affairs. Wronged as Cromwell might be, he still sticks to the ethical principle of loyalty to the king and patriotism. Besides, Cromwell spears no effort to serve Henry VIII, and can read him like a book. He would do in person whatever is concerned with the king's comfort, and ensure everything is infallibly done. When Henry VIII desires to get rid of Anne and marry Jane Seymour, and Cromwell strives to charge her with "treason and adultery". Henry VIII is busily employed in winning young girls' heart, while Cromwell deals with common affairs, like war and peace, famine, connivance of betrayals, stubbornness of citizens, plague, king's loss in gambling, etc. Cromwell is all about work, always the last person to sleep and the first to rise. He is preoccupied with national political tensions and persuades the king from launching warfare, freeing the subjects from suffering.

Cromwell dreams to establish a unified country with a unified currency, a unified measure, and in particular, a unified language everyone can use. His great expectation of England is that king's interest is accordance with interest of the state, and that everybody does what they should do. As a loyal and patriotic courtier of Tudor Dynasty dating back to the 16th century, Cromwell has made a great contribution to the society and has laid a solid foundation for modern England. History is a reflection of reality, and with the development and maturity of modern society, the moral principle of loyalty to the king shall perish when there is no king to pledge loyalty to. However, when confronted with contradictions and alienation during the course of evolution, we moderns can transform Cromwell's ethnic principles of loyalty and patriotism into public rational spirits of adherence, responsibility, loyalty, and honesty, which is of important reference value to the construction of modern public culture.

\section{Construction of Healthy Marriage and Family Relationship in Light of Natural Humanism}

Witty and persuasive, Mantel presents a picture of Tudor Dynasty dated back to 16th century in Wolf Hall and Bring up the Bodies, in which marriage of Henry VIII is closely related with the rise and fall of Cromwell. Marriage is dominated by Christian ideology which is prevalent at that particular historical period. Besides, marriage is both a shared life status reached in accordance with will of both spouses, and a sacred system established between a man and a women who are baptized at a Christian church, the foremost purpose being breeding and cultivating offspring. Christian advocates monogamy and loyalty to marriage and objects to divorce, 
which facilitates the stability of marriage. Prior to the Reformation, Tudor dynasty follows the belief of Roman Catholic and deems Pope as embodiment of the supreme power. Stories in these two novels are unfolded in this particular historical context. After Henry VIII's succession to the throne, he married his brother's widow, Katherine of Aragon, as the first queen. When ages find flesh stop clinging, and worse still, Katherine does not give birth to a male heir. Henry VIII is sick and tired of Katherine, plotting to discard her and marry Anne Boleyn, Katherine's lady-in-waiting. Yet such thought is strongly opposed by the pope and a divorce and remarrying would be intolerable. Cromwell strives to break the deadlock and allows the king his heart's desire, declaring the 20-odd-year marriage between Henry VIII and Katherine invalid, and leaving the latter to her devices. But alas, the second marriage only brings to Henry VIII a feeble princess Elizabeth, and Anne falls into disfavor for her failure to give birth to male heirs. The faithless and ruthless king wants to get rid of Anne and marry Jane Seymour. However, confined by the strict rules of the church, nature of marriage is defined as monogamy and irrevocability. Separation and revocation of marriage is grounded on adultery, being blood-related, religious relations, impotence, or death on part of one spouse (Bo, 2005). The ambitious Anne is unwilling to renounce queenship and seclude in the monastery, thus relationship between Henry VIII and Anne deteriorates. Cromwell plots to plant adultery and treason on Anne who later is beheaded. Marriage of royal family is vividly depicted for the very reason that it is the main plot. More importantly, marriage of royal family is in sharp contrast to the imagined ethical marriage of Cromwell. Suppose marriage of Henry VIII is a political one lacking in spousal sentiments and love, Cromwell's marriage and family is a perfect and ethical utopia.

Cromwell, a man of humble birth, rises to power, and marries Liz, daughter of a wool trader and a widow, who has bred Gregory, Anne, and Grace. It is a happy marriage and family, the husband working and providing for family, and the wife helping husband and breeding kids. In the aftermath of plague which has claimed lives of Cromwell's wife and daughters, he sticks with his kids and plans the future of family, instead of giving up on his marriage and family. However, the night always finds him solitary and reminiscent of his wife and daughters, which reflects natural and profound humanity in him.

\section{Construction of Ethical Relationship on the Principle of Righteousness and Kindness}

Ethic relationship is interpersonal relations as regards ethics and is one of the most commonplace social relationship. It synchronizes with origin of human kind, and becomes more important and complex with the development of society, hence it is an important measure of the status quo of society. In these two novels, righteousness and kindness is both the foundation of ethics by which Cromwell lives and Mantel's review and reflection of social ethics in worldly life. As for his old master Cardinal Thomas Wolsey, Cromwell takes him as "a father, a mentor and a friend". Cromwell has witnessed the fall of Wolsey, but never turns his back on him and leaves him. Cromwell feels sorry for Wolsey for the rest of his life, and is still drenched in regret and distress even after he replaces Wolsey, wielding power and beheading those who have insulted and sneered at Wolsey. Friendship is best suited to the nature of human beings and friendly ethics includes understanding, appreciation, trust, tolerance, sacrifice, and many other virtues.

Two main friends of Cromwell are Thomas Cranmer, Archbishop of Canterbury, and Thomas Wyatt, a smart and versatile gentleman. Cromwell is quite chivalrous and generous to his friends, who have never been brought to books. When Cranmer, bringing along his pregnant wife, turns to him at the risk of death, Cromwell 
does not hesitate to lend a helping hand and takes care of Cranmer's wife, regardless of the fact that his reputation might be ruined. When Anne is accused of adultery and treason, Wyatt is dragged through the court, Cromwell frequently visits him and uses all his muscles to get Wyatt out. Not only is Cromwell righteous and generous, but also always benevolent and loving, sympathizing with the weak and caring for the mass. When he sees businessmen hoard grains and intends to increase prices, he wishes he could hang those illegal businessmen. When he sees several Londoners fight for relief bread and are trampled to death, he is so worried. He rescues 10 plus boys from monastery, making them learn music under his roof and also distributes broth and bears among the poor who suffer from hunger and cold. Furthermore, Cromwell has solicitude for his opponent Thomas More, who, in his eyes, is a stubborn apologist lacking in conscience. Despite the fact that More would rather be arrested and punished than pledge the oath of loyalty to the king, Cromwell cares for him and visits him in prison, attempting to persuade him to change his mind. Cromwell bribes the gatekeeper and makes him take care of More: "At night his breath comes short. Bring him some bolsters, cushions, whatever you can find, prop him up to ease him. I want him to have every opportunity to live to rethink his position, show loyalty to our king, and go home" (Mantel, 2010, p. 579). More stands in the way of political career and Cromwell would have him killed if the issue is to be settled from political approach. However, Cromwell hates to see the talented and learned More die a painful death. Hence Cromwell does whatever he can to save and protect More, who, in turn, takes Cromwell as "most especial and tender friend" (Mantel, 2010, p. 544).

Apparently, the vivid portrait of such ethical principles as loyalty, patriotism, healthy marriage, harmonious family, righteousness, and benevolence embodied by Cromwell mirrors the pursuit of Utopia. The introduction of ideal life model to noisy and degraded worldly life is intended for an epiphany of ethics. Humanities, harmonious interpersonal relationship, and moral principle centered on righteousness and benevolence are basic properties of ethics. With the development of modern Capitalism, sophisticated technology and computation idealize everything, making human slaves to machines, money, and bureaucracy. Given "the irrational lifestyle, which is a consequence of idealization" ( $\mathrm{Su}, 2013)$, Mantel endows Cromwell with such special ethical traits, namely, the relentless pursuit of ethics in the context of modern ethical prescriptivism and irrational emotionalism. Much emphasis is laid on the moral character and personalities in modern society, where moral principles are placed in jeopardy by the fundamental upset of orders due to modernism and cannot be remedied from the broad sense.

As a radical form of thought, literature and art directly give vent to the urgent historical desire of modernity, and cry for historical revolutions. In the meanwhile, it is also a conservative force of emotion, and questions and meditates upon the evolution of modernism. In a word, construction of moral utopia in Mantel's works reflects her contemplation on modern ethics.

\section{References}

Bo, J. P. (2005). As god is the witness. Beijing: Academia Press.

Jameson, F. (1995). Marxism and form: Twentieth-century dialectical theories of literature. (Z. X. Li, Trans.). Nanchang: Baihuazhou Literature and Art Press.

Jiang, G. X. (1988). Rationalization and its limitation. Shanghai: Shanghai People's Publishing House. Lukács. (2004). Selected early works of Lukács. (L. Zhang \& Y. L. Wu, Trans.). Nanjing: Nanjing University Press. Mental, H. (2010). Wolf Hall. (G. Z. Liu et al., Trans.). Shanghai: Shanghai Translation Publishing House. Wu, M. G. (2013). From narrative to ethics: Theory and practice of narrative ethics. Beijing: Xinhua Press. 
Yin, Q. P. (1995). On the art of novel. Tianjin: Baihua Literature and Art Press.

Zou, L. (2006). On the marital relationship between the West and China under the domination of christianity and feudal ethical code. Journal of Yunnan Finance \& Economics University, 21(2), 14. 